\title{
Rancang Bangun Aplikasi Sistem Informasi Geografis Objek Wisata dan Kuliner di Kabupaten Kudus Berbasis Smartphone Android
}

\author{
Aris Nurhindarto', Della Rezha Santoso², Erwin Yudi Hidayat ${ }^{3}$ \\ Fakultas Ilmu Komputer, Universitas Dian Nuswantoro \\ e-mail: ${ }^{1}$ arisnurhindarto@dsn.dinus.ac.id, ${ }^{2} 112201605490 @$ mhs.dinus.ac.id, \\ 3erwin@dsn.dinus.ac.id
}

Diterima: 12 Desember 2020; Direvisi: 28 Desember 2020; Disetujui: 28 Desember 2020

\begin{abstract}
Abstrak
Teknologi informasi dan komunikasi saat ini semakin pesat hingga memajukan kebutuhan manusia mengenai informasi yang cepat dan akurat. Seperti halnya pada bidang pariwisata, dibutuhkan informasi guna memudahkan wisatawan dalam mendapatkan informasi tujuan wisata dan kuliner yang akan dituju. Promosi yang digunakan untuk menarik wisatawan menggunakan media massa semacam penyebaran pamflet, leaflet, brosur, tetapi dalam melakukan metode tersebut masih minim untuk bisa menginformasikan kepariwisataan secara meluas kepada wisatawan. Tujuan dari perancangan aplikasi Geographic Information System dengan menggunakan Smartphone untuk mengidentifikasi persebaran objek wisata dan kuliner. Metode pengembangan yang diterapkan pada penelitian ini yaitu metode Prototyping dengan menggunakan pemodelan Unified Modelling Language (UML). Dengan berdasarkan hasil dari pengujian black box, maka dapat disimpulkan aplikasi yang telah dirancang ini dapat direkomendasikan untuk media pendukung navigasi menuju objek wisata dan kuliner sehingga bisa digunakan sebagai sarana peningkatan untuk Dinas Kebudayaan dan Pariwisata Kota Kudus. Hasil penelitian dapat disimpulkan bahwa perancangan aplikasi untuk pemetaan persebaran objek wisata dan kuliner di Kabupaten Kudus berbasis Geografic Information System (GIS) dapat mempermudahkan pengguna dalam mencari informasi mengenai lokasi menuju tempat wisata atau kuliner. Dengan berdasarkan kategori yang telah dipilih, wisatawan dapat mengetahui arah peta berdasarkan titik awal menuju ke lokasi yang akan dituju oleh wisatawan.
\end{abstract}

Kata kunci: sistem informasi geografis, android, tourism, prototyping

\begin{abstract}
Information and communication technology is currently growing rapidly, advancing human needs regarding fast and accurate information. As in the tourism sector, information is needed to make it easier for tourists to find the tourist and culinary destinations to go to. Promotion that is used to attract tourists uses mass media such as the distribution of pamphlets, leaflets, brochures, but in doing so these methods are still minimal to inform tourism widely to tourists. The purpose of designing the Geographic Information System application using a Smartphone is to identify the distribution of tourist and culinary objects. The development method applied in this research is prototyping method using the Unified Modeling Language (UML). Based on the results of the black box testing, it can be concluded that this application that has been designed can be recommended as a kind of supporting media for navigation to tourist and culinary objects so that it can be used as an enhancement medium for the Kudus City Culture and Tourism Office. So that it can be concluded that the design of this study on the mapping of the distribution of tourist and culinary objects in Kudus Regency based on the Geographic Information System (GIS) can make
\end{abstract}


it easier for users / tourists to find information about locations to tourist or culinary spots. Based on the categories that have been selected, tourists can find out the direction of the map based on the starting point to the location that tourists will go to..

Keywords: GIS, android, tourism, prototyping

\section{PENDAHULUAN}

Kabupaten Kudus merupakan sebuah kabupaten yang memiliki luas tersempit di Jawa Tengah yaitu sekitar $42.516 \mathrm{Ha}$, terdiri dari 9 kecamatan dan 131 desa. Kabupaten Kudus berada di jalur strategis transportasi regional antara Surabaya-Semarang-Jakarta, letak geografis Kabupaten Kudus yaitu di sebelah barat (Kabupaten Demak), sebelah utara (Kabupaten Jepara), sebelah selatan (Kabupaten Grobogan), dan sebelah timur (Kabupaten Pati). Kabupaten Kudus dikenal dengan latar belakang agamis sebagai kota industri dan perdagangan [1].

Kabupaten Kudus merupakan sebuah kota yang memiliki potensi pariwisata yang beragam yang menjadikan Kabupaten Kudus memiliki daya tarik wisatawan. Salah satunya yaitu terdapat beberapa tempat objek wisata dan wisata kuliner yang tergolong khas yang bisa dikunjungi bagi wisatawan lokal maupun wisatawan mancanegara, namun tidak semua wisata dan kuliner yang terdapat di Kabupaten Kudus ini dapat diketahui oleh para wisatawan, karena sedikitnya ketersediaan informasi tentang pariwisata yang menjadikan wisata dan kuliner di daerah Kabupaten Kudus kurang diketahui oleh wisatawan. Sehingga menyebabkan wisatawan kesulitan dalam menentukan tujuan dan rencana perjalanan.

Meskipun pemerintah pada Kabupaten Kudus sudah berupaya dalam mengadakan promosi dengan media massa semacam penyebaran pamflet, leaflet, brosur, tetapi dalam metode tersebut masih minim dalam menginformasikan kepariwisataan secara meluas kepada wisatawan. Minimnya informasi yang didapat wisatawan tentang kepariwisataan Kabupaten Kudus dikarenakan Dinas Kebudayaan dan Pariwisata Kabupaten Kudus masih belum melakukan promosi dengan teratur dan penyampaian informasi dalam bentuk media massa masih bersifat sementara. Walaupun saat ini sudah tersedia di berbagai situs website tentang objek wisata dan kuliner, namun untuk mencari lokasi yang diinginkan oleh wisatawan tersebut masih tersebar di berbagai website, sehingga dalam pencarian lokasi tersebut jika menggunakan browser mobile akan terasa berat dalam memprosesnya, hal ini juga dapat memakan waktu lama dan kurangnya informasi yang belum lengkap.

Dengan melihat perkembangan kemajuan teknologi saat ini yang semakin pesat, tentu kian efektif apabila informasi pariwisata tersebut digabungkan dengan memanfaatkan kemajuan teknologi seperti smartphone. Selain itu perkembangan teknologi ini juga memiliki peranan penting bagi beberapa sektor bidang, termasuk salah satunya yaitu pada bidang kepariwisataan. Karena di dalam bidang kepariwisataan tersebut terdapat faktor yang dapat mempercepat pertumbuhan ekonomi pada Kabupaten Kudus. Sebab itu kini teknologi sudah menjadi kebutuhan yang sangat marak digunakan oleh manusia sehingga informasi tentang wisata dan kuliner pun dapat lebih mudah untuk didapatkan dan memiliki manfaat untuk memudahkan para penggunanya dalam mendapatkan sebuah informasi dengan cepat dan akurat.

Pada dasarnya kemajuan teknologi smartphone masa sekarang ini bukan sekedar dapat digunakan dalam berkirim pesan, mendengarkan musik, tetapi juga dapat digunakan untuk mengakses internet dan GPS. Seiring dengan perkembangannya, teknologi smartphone merupakan salah satu tren dan kebutuhan yang dapat menjadikan peluang bagi peningkatan layanan publik. Sehingga perangkat ini tidak hanya digunakan sebagai alat untuk komunikasi saja tetapi juga sebagai media yang bisa digunakan untuk mempengaruhi pangsa pasar smartphone diantara platform lainnya. Sistem operasi pada smartphone saat ini juga semakin bertambah dan beraneka macam, beberapa diantaranya meliputi Android, Microsoft Windows Mobile dan Symbian. Sistem operasi pada smartphone yang memiliki keunggulan dari pada sistem operasi 
lainnya yaitu Android, sistem operasi ini bersifat open source dan memiliki kinerja multitasking yang cukup baik.

Karena itu dipilih sistem operasi Android sebagai platform pengembangan aplikasi yang mampu memberikan solusi kepada masyarakat khususnya dalam bidang kepariwisataan. Dengan adanya aplikasi mobile Android ini, maka wisatawan dapat lebih mudah dalam pencarian wisata dan kuliner yang tersebar di Kabupaten Kudus. Dimana dengan mengkombinasikan teknologi komunikasi dan komputerisasi dengan terintegrasi berbagai aktivitas.

Global Positioning System (GPS) merupakan teknologi yang sedang berkembang yang dapat digunakan untuk mengetahui lokasi. Integrasi teknologi GPS dan internet dikembangkan dengan mobile interaktif yang berbasis lokasi. Geographic Information System (GIS) adalah pola yang bisa menyebarkan suatu penjelasan berupa peta, GIS banyak digunakan dalam bidang ini dengan memanfaatkan media visual.

Implementasi dari integrasi smartphone mobile Android berbasis GIS inilah yang menjadi salah satu penyelesaian untuk persoalan tersebut. Untuk dapat memberikan informasi mengenai rute yang akan dilalui untuk sampai di wisata-wisata yang ada di Kabupaten Kudus termasuk juga wisata kuliner, sehingga dibutuhkan sebuah sistem operasi Android pada smartphone dengan berbasis GIS. Dengan aplikasi tersebut maka diharapkan para wisatawan dapat memanfaatkan aplikasi untuk mendapatkan suatu informasi secara cepat dan realtime.

Penelitian ini memaparkan aplikasi smartphone berbasis GIS yang disajikan dalam bentuk peta dapat menyampaikan suatu informasi tentang nama dan lokasi objek wisata, serta tempat kuliner yang ada di Kabupaten Kudus. Penyusunan penelitian disusun dengan memaparkan tinjauan studi terlebih dahulu terhadap penelitian-penelitian sebelumnya sebagai bahan referensi. Pada bagian ini ada beberapa rujukan yang berhubungan dengan jurnal penelitian yang dilakukan. Berikut adalah beberapa jurnal penelitian terdahulu.

Penelitian oleh [2] yang berjudul "Pembuatan Aplikasi Mobile GIS Berbasis Android untuk Informasi Pariwisata di Kabupaten Gunung Kidul”. Berdasarkan hasilnya penelitian ini, mampu membuat aplikasi yang bisa digunakan dengan memanfaatkan mobile GIS tentang pariwisata di Kabupaten Gunung Kidul. Fitur-fitur yang ada pada aplikasi dalam mobile ini meliputi petunjuk arah lokasi, jarak ke lokasi, dan informasi tentang wisata Gunung Kidul. Penelitian oleh [3] yang berjudul "Aplikasi Navigasi Objek Wisata Kabupaten Lingga Berbasis Mobile". Penelitian ini menghasilkan pengujian UAT terhadap sistem backend yaitu 92,5\%. Sedangkan pengujian terhadap aplikasi navigasi $95 \%$ yang menunjukan tingkat penerimaan baik. Penelitian oleh [4] yang berjudul "Pengembangan Sistem Informasi Pariwisata Kota Palembang Berbasis Mobile Android". Berdasarkan hasil pengujian yang dilakukan memberikan kesesuaian perancangan sistem dengan pengimplementasian sistem yang dapat berjalan dengan baik.

Penelitian oleh Erik Kurniadi dan Heru Budianto di tahun 2018 yang berjudul "Rancang Bangun Aplikasi Wisata Kabupaten Kuningan Berbasis Android menggunakan Metode Location Based Service (LBS)". Berdasarkan hasil dari metode yang digunakan ini user dapat memberikan input aplikasi berupa pilihan lokasi objek wisata di daerah Kabupaten Kuningan dengan lokasi wisata yang terpilih akan dikirimkan ke database wisata dan koordinat user akan dikirimkan ke server Google Maps API sehingga aplikasi akan menunjukan peta dan rute tujuan wisata, serta informasi detail lokasi tujuan. Selain itu layanan yang digunakan adalah layanan full service atau layanan yang hanya diberikan ketika ada permintaan dari pengguna [5].

Penelitian oleh Ghilman Basith dan Dede Kurniadi di tahun 2017 yang berjudul "Perancangan Sistem Informasi Pemetaan Pariwisata Garut Berbasis Geographic Information System dan Android". Dalam hal ini metode perancangan sistem yang digunakan untuk mengatasi masalah tersebut yaitu melalui memanfaatkan metode RAD. Berdasarkan hasil penggunaan metode RAD tersebut, maka suatu sistem aplikasi pemetaan berbasis GIS dan android dapat menampilkan data pariwisata. [6].

\section{METODE PENELITIAN}


Pengembangan aplikasi dilakukan dengan menggunakan pendekatan prototyping, pendekatan ini dipilih dengan keunggulan dimana komunikasi antara pengembang dan pengguna cenderung lebih intens dan lebih baik. Analis sistem dapat bekerja dengan lebih baik karena keterlibatan pengguna secara aktif dalam membantu pendefinisian kebutuhan memungkinkan tersusunnya dokumen system requirements specification ( $S R S$ ) yang lebih jelas dan valid. Respon terhadap feedback yang disampaikan oleh pengguna terkait dengan deliverable yang ditunjukkan secara bertahap menghindarkan pengembang dari kesalahan yang lebih fatal [7]. Namun demikian penulis tetap mewaspadai sejumlah potensi kegagalan dari pengembangan sistem menggunakan pendekatan ini, yang diantaranya adalah faktor ketergesaan dalam konstruksi dan implementasi sistem.

Secara umum langkah operatif yang dilakukan dengan menggunakan pendekatan prototyping ini meliputi:

1. Mengidentifikasi kebutuhan pemakai secara iteratif untuk mendapatkan paparan gagasan berkenaan dengan requirement yang valid dan detil. Wawancara dilakukan dengan sejumlah pengguna berpotensi yang meliputi penyedia jasa kuliner dan pengelola lokasi wisata, komunitas penggemar wisata kuliner, serta agen tour dan travel.

2. Perancangan aplikasi secara cepat yang menekankan pada penyampaian desain software secara bertahap, bukan menunggu hingga keseluruhan aplikasi selesai dirancang.

3. Pengembangan kode program dengan cepat dimana deliverable yang ditekankan pada representasi dari aplikasi dari sudut pengguna; yang mencakup bentuk inputan dan format output. Penyampaian dilakukan secara progresif berdasarkan fitur atau menu atau laporan.

4. Evaluasi prototipe yang dilakukan oleh user dan pengembang untuk memastikan kebutuhan pengguna telah teradopsi dengan baik dan untuk mendapatkan umpan balik perbaikan dari pengguna. Apabila prototipe dapat diterima maka proses pengembangan untuk modul-modul lainnya dapat dilanjutkan, namun apabila terdapat feedback atau perubahan kebutuhan maka tahapan pada langkah ke-2 akan dilakukan kembali.

\section{HASIL DAN PEMBAHASAN}

\subsection{Pengumpulan Kebutuhan (Requirement)}

Berdasarkan analisis yang didapatkan hasil kebutuhan yang dibutuhkan dari pengguna adalah aplikasi harus mengakomodir 5 kegiatan seperti:

1. Locating, yaitu mengetahui lokasi dimana seorang pengguna berada.

2. Searching, yaitu mencari lokasi suatu objek wisata dan kuliner yang akan dituju.

3. Navigating, yaitu menanyakan arah untuk mencapai suatu lokasi yang akan tertuju.

4. Identifying, yaitu menanyakan properti dari suatu lokasi tertentu.

5. Checking, yaitu mencari suatu kejadian dalam lokasi tertentu.

Aplikasi mobile ini merupakan aplikasi yang dirancang agar pengguna dimudahkan dalam menentukan suatu tempat objek wisata dan kuliner yang tersebar pada wilayah Kabupaten Kudus dengan menggunakan teknologi GIS. Dimana dalam teknologi GIS dapat digunakan untuk menangkap informasi geografis dengan mudah. Tetapi pada umumnya dalam melakukan pengumpulan dan editing data memerlukan waktu banyak dan sering terjadi kesalahan. Karena itu teknologi GIS diimplementasikan sebagai peta digital mobile computer dengan informasi yang dapat ditambahkan secara real time ke database sehingga dalam pengambilan keputusan data dapat up-to-date dan akurat.

Salah satu bagian dari pengimplementasian mobile GIS yaitu teknologi Location Based Service (LBS) yang cenderung memberikan fungsi terapan, misalnya menampilkan directory city, navigasi, pencarian, pada teknologi GIS untuk Field Based GIS. Sebab itu Location Based Service (LBS), bekerja dengan bantuan peta dari Google Maps yang ditambah dengan informasi berupa Latitude dan Longitude (titik koordinat) dapat memberikan suatu informasi berguna untuk pengguna. 
Adapun penerapan dalam Location Based Service (LBS) ini dimulai dari seorang user atau wisatawan yang memberikan input pada aplikasi berupa pilihan daftar objek wisata dan kuliner yang ada di Kabupaten Kudus, sebagaimana tampak pada gambar 1. Daftar objek wisata dan kuliner tersebut yang nantinya terpilih oleh user akan dikirimkan ke database. Selanjutnya objek wisata dan kuliner dan koordinat user akan dikirimkan ke server Google Maps API sehingga nantinya aplikasi tersebut akan menunjukkan peta dan rute tujuan objek wisata dan kuliner yang telah dipilih oleh user sebelumnya. Selain itu pada aplikasi ini memberikan layanan pull service atau layanan yang hanya memberikan ketika ada permintaan dari seorang pengguna.

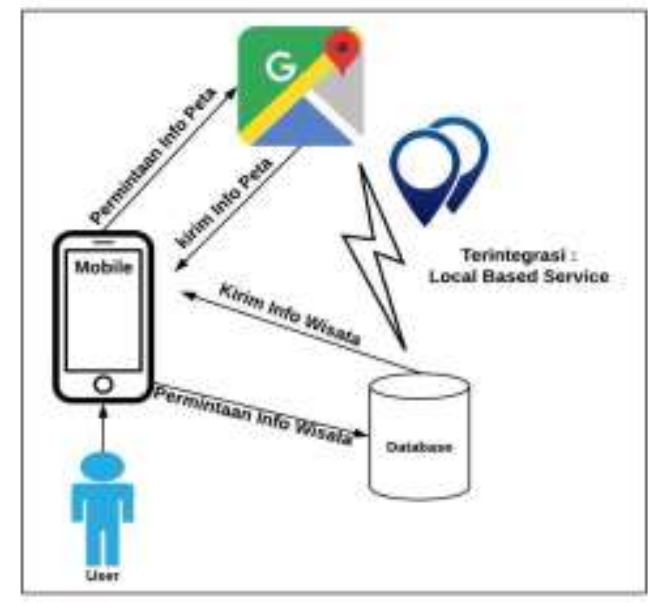

Gambar 1. Rancangan Sistem

Paparan arsitektur sistem secara umum tampak pada Gambar 2, dimana dua database utama yang berperan dalam aplikasi ini akan menyangga kebutuhan informasi lokasi secara real (melalui server Google Maps) dan kebutuhan data serta informasi terkait tempat wisata dan kuliner yang berada di Kabupaten Kudus (melalui server Database local). Entri data baru atau modifikasi data lama dapat dilakukan oleh pengguna yang berperan sebagai pengelola melalui sistem backend yang berbasis web. Sementara itu permintaan atau request data yang dilakukan oleh pengguna yang berperan sebagai naïve user akan dilayani melalui sistem berbasis mobile. Sinkronisasi secara periodik dilakukan pada kedua sistem untuk menjamin validitas informasi yang disampaikan.

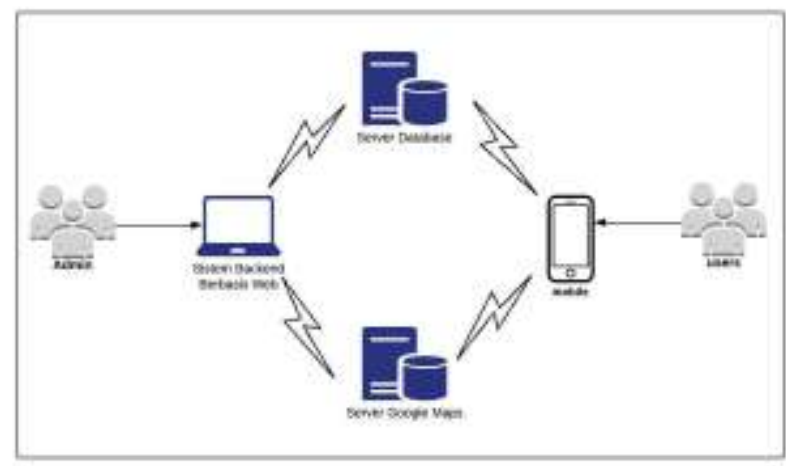

Gambar 2. Arsitektur Sistem

\subsection{Use Case Diagram}

Pemodelan use case merupakan suatu bentuk pemodelan sistem yang berupa pandangan dari perspektif pengguna akhir (end user). Sistem ini mendeskripsikan penggunaan dalam aplikasi persebaran informasi mengenai objek wisata dan kuliner yang ada di Kabupaten Kudus. Pada 
pemodelan use case digambarkan functionality dari dua aktor yakni naïve user dan administrator (gambar 3). Nä̈ve user pada diagram ini dapat diasumsikan sebagai wisatawan atau masyarakat umum yang dapat mengakses secara langsung layanan dalam aplikasi mengenai objek wisata dan kuliner di Kabupaten Kudus. Pada aplikasi ini user dapat melihat halaman utama dari aplikasi objek wisata dan kuliner dan melakukan tiga interaksi antara lain dapat mengakses menu pilih tentang aplikasi, menu objek wisata, menu wisata kuliner. Sedangkan admin memiliki lima interaksi antara lain login, kelola data admin, kelola data wisata, kelola data kuliner, kelola data tentang aplikasi. Berikut pemodelan use case diagram pada aplikasi persebaran objek wisata dan kuliner di Kabupaten Kudus menggunakan smartphone Android.

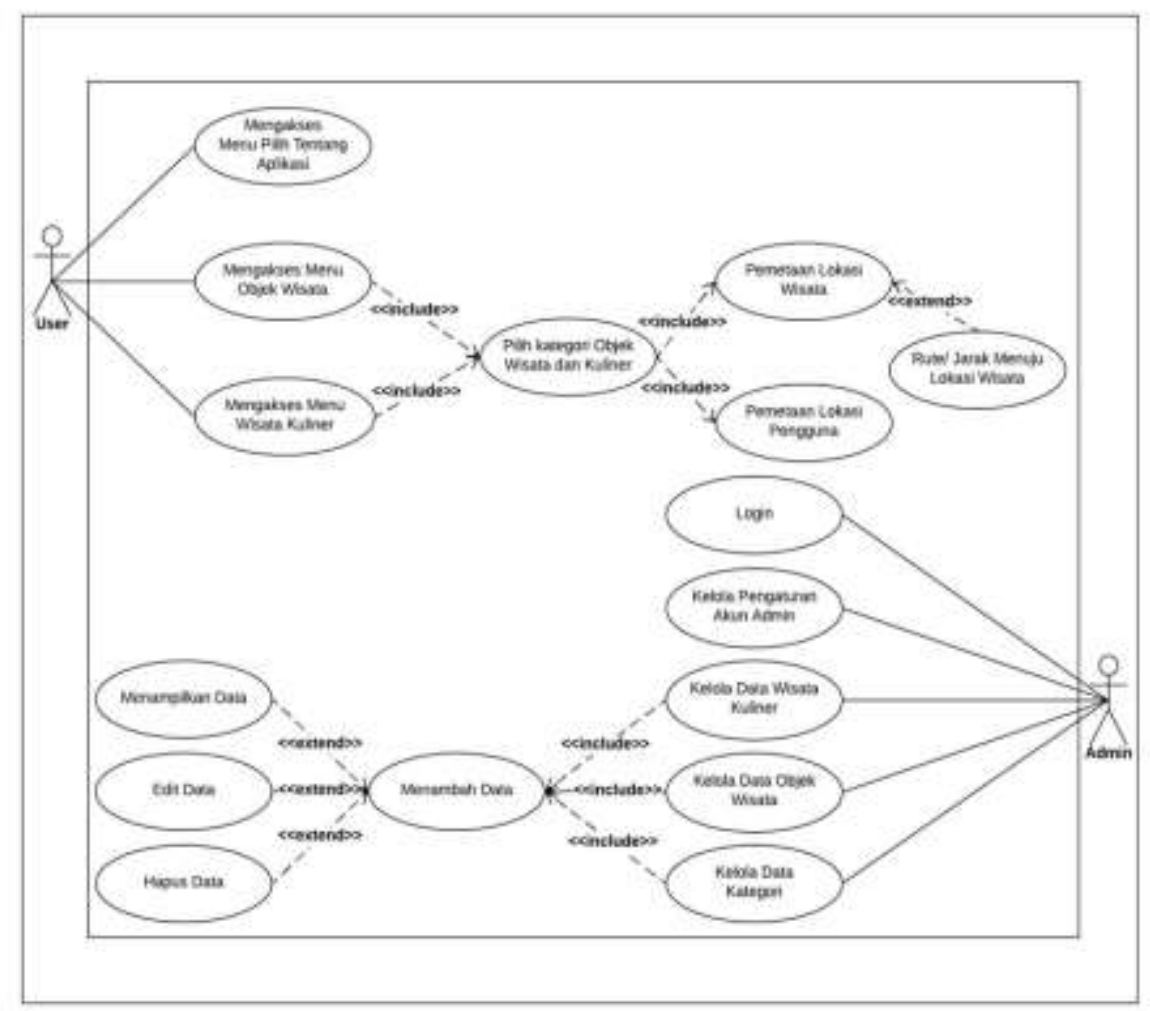

Gambar 3. Use Case Diagram

Rincian dari use case diagram dapat dilihat pada tabel deskripsi interaksi user dengan sistem berikut ini.

Tabel 1. Interaksi Antar Aktor dan Sistem

\begin{tabular}{|c|c|}
\hline Use Case Diagram & Deskripsi \\
\hline Mengakses Menu Pilih & Use case ini digunakan untuk memberikan user informasi yang ada di \\
\hline $\begin{array}{l}\text { Tentang Aplikasi, } \\
\text { Wisata dan Kuliner. }\end{array}$ & $\begin{array}{l}\text { Kabupaten Kudus sehingga, pengguna aplikasi dapat mengetahui informasi } \\
\text { yang telah diberikan dan menggambarkan kegiatan melihat daftar Objek } \\
\text { Wisata yang ada berdasarkan dengan kategori wisata dan kuliner. }\end{array}$ \\
\hline Login. & $\begin{array}{l}\text { Use case ini menggambarkan kegiatan admin saat memasukkan id dan } \\
\text { password untuk dapat mengakses sistem. }\end{array}$ \\
\hline $\begin{array}{l}\text { Kelola Pengaturan } \\
\text { Akun Admin. }\end{array}$ & $\begin{array}{l}\text { Use case ini digunakan untuk mengelola data admin agar dapat mengubah } \\
\text { data admin dan password yang dimiliki ataupun dapat menambah data user } \\
\text { pada admin. }\end{array}$ \\
\hline Kelola Data & $\begin{array}{l}\text { Use case ini menjelaskan bagaimana admin mengelola data wisata } \\
\text { berdasarkan kategori yang ada. }\end{array}$ \\
\hline $\begin{array}{l}\text { Manajemen } \\
\text { Admin. }\end{array}$ & $\begin{array}{l}\text { Use case ini menggambarkan proses pengelolaan data seperti, menambah, } \\
\text { memperbarui, dan menghapus data wisata. }\end{array}$ \\
\hline
\end{tabular}


Dari Tabel 1 dapat dijelaskan bahwa record pertama merupakan deskrispsi dari case yang dimiliki oleh actor user sementara record lainnya merupakan deskripsi dari case yang dimiliki oleh actor admin. Selain memberikan akses untuk mengetahui informasi wisata dan kuliner di wilayah Kabupaten Kudus, use case pada actor user ini juga memungkinkan user mengetahui rute menuju ke lokasi yang dipilih dengan rute yang tercepat dengan memanfaatkan platform Maps Google. Sementara itu use case dari actor admin didominasi dengan fungsi manajemen data wisata dan kuliner yang meliputi penambahan, penghapusan, dan modifikasi semua tabel yang terkait dalam aplikasi.

\subsection{Skenario Sistem}

Skenario sistem merupakan alur jalannya suatu proses use case diagram dari aktor dan sistem. Berikut pada tabel 2 adalah uraian rinci dari use case yang ada di dalam aplikasi persebaran objek wisata dan kuliner di Kabupaten Kudus menggunakan smartphone Android.

Tabel 2. Skenario Use Case Mengakses Menu Objek Wisata

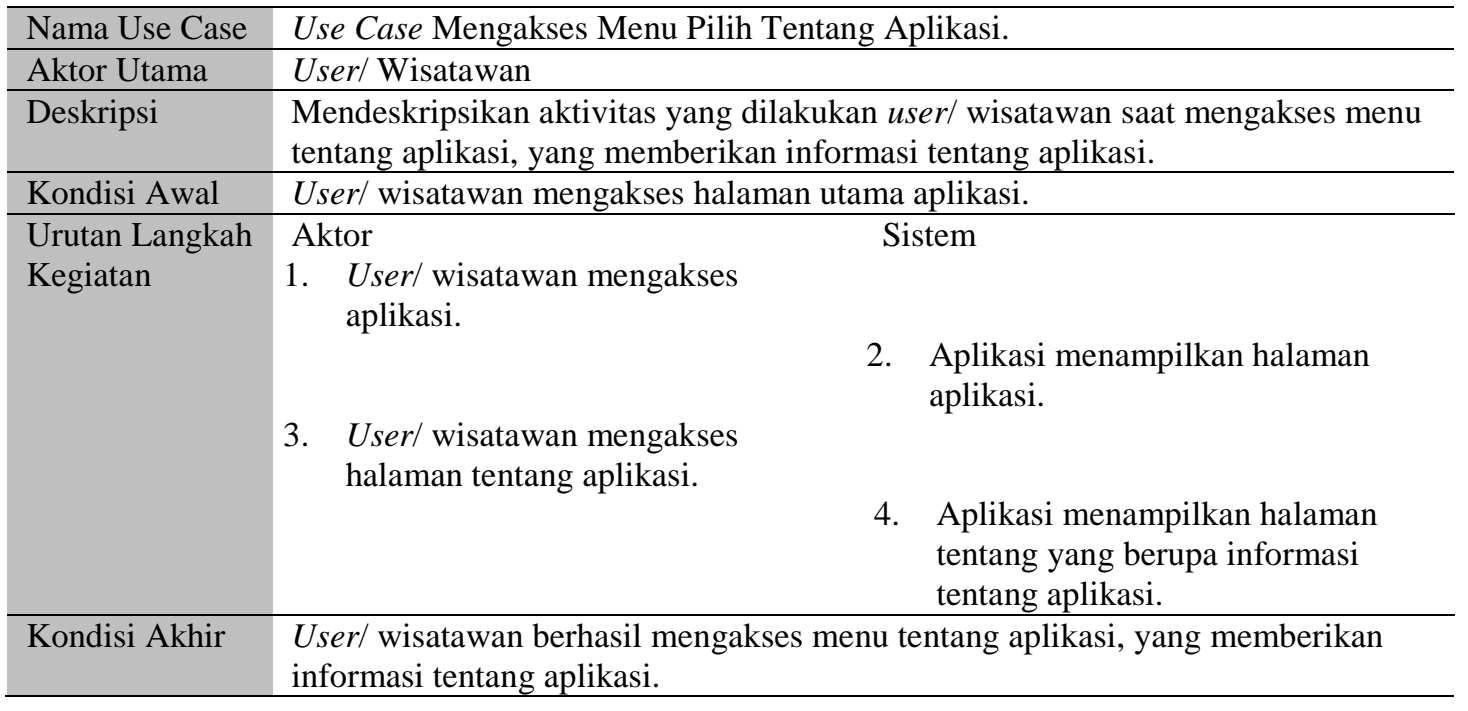

\subsection{Perancangan Database GIS Objek Wisata dan Kuliner}

Database merupakan suatu penyimpanan data secara terstruktur agar data dapat digunakan dengan baik. Dengan kata lain database berisi kumpulan data operasional dari suatu organisasi atau perusahaan yang dikelola secara terintegrasi dengan menggunakan metode tertentu, menggunakan komputer. Sehingga mampu menyediakan informasi secara optimal bagi pengguna. Perancangan database pada aplikasi GIS sebagai berikut:

1) Tabel Kategori, Tabel ini digunakan sebagai penyimpanan hasil inputan data kategori yang dilakukan admin. Struktur data tabel kategori dapat dilihat sebagai berikut:

Tabel 3. Tabel Kategori

\begin{tabular}{rccc} 
No & Field & Type & Keterangan \\
\hline 1. & id_kategori* & Int $(11)$ & Kode Kategori $(1,2,3,4, \ldots)$ \\
2. & jenis_objek & Varchar (30) & Jenis Kategori \\
3. & kategori & Varchar (30) & Kategori \\
\hline
\end{tabular}


2) Tabel Wisata, Tabel ini berfungsi sebagai penyimpan hasil penginputan data objek wisata Kabupaten Kudus yang dilakukan oleh admin. Struktur data tabel wisata dapat dilihat sebagai berikut:

Tabel 4. Tabel Wisata

\begin{tabular}{llll}
\hline No & Field & TypeA & Keterangan \\
\hline 1. & id_wisata* & Int $(20)$ & Kode Wisata $(1,2,3,4, \ldots)$ \\
2. & id_kategori** & Int $(11)$ & Kode Kategori $(1,2,3,4, \ldots)$ \\
3. & nama_kota & Varchar $(30)$ & Nama Kota \\
4. & nama_tempat & Varchar $(50)$ & Nama Tempat \\
5. & alamat & Text & Alamat \\
6. & latitude & Varchar (20) & Latitude Lokasi \\
7. & longitude & Varchar $(20)$ & Longitude Lokasi \\
\hline
\end{tabular}

Sebagaimana tampak pada Tabel 4, dimana id_wisata dan id_kategori merupakan primary dan secondary key. Untuk field nama_kota merujuk pada kota kecamatan yang ada pada Kabupaten Kudus, sedangkan untuk nama_tempat merujuk pada nama resmi dari suatu lokasi wisata atau kuliner yang terdaftar pada dinas pariwisata Kabupaten Kudus. Field latitude berisi nilai sudut 0 - \pm 90 dimana tanda + (positif) menunjukan arah ke atas menuju kutub utara, sedangkan tanda - (minus) di koordinat Latitude menuju ke kutub selatan. Sementara itu field longtitude (garis lintang) merujuk pada angka dari sudut bundar bumi horisontal. Titik diawali dari 0 ke 180 derajat, dan 0 ke-180 ke arah sebaliknya [8].

3) Tabel Kuliner, Tabel kuliner ini berfungsi sebagai penyimpan hasil penginputan data kuliner Kabupaten Kudus yang dilakukan oleh admin. Struktur data tabel kuliner dapat dilihat sebagai berikut:

Tabel 5. Tabel Kuliner

\begin{tabular}{clll}
\hline No & \multicolumn{1}{c}{ Field } & \multicolumn{1}{c}{ Type } & \multicolumn{1}{c}{ Keterangan } \\
\hline 1. & id_kuliner* & Int $(20)$ & Kode Kuliner $(1,2,3,4, \ldots)$ \\
2. & id_kategori** & Int $(11)$ & Kode Kategori $(1,2,3,4, \ldots)$ \\
3. & nama_kota & Varchar (30) & Nama Kota \\
4. & nama_tempat & Varchar (50) & Nama Tempat \\
5. & alamat & Text & Alamat \\
6. & latitude & Varchar (20) & Latitude Lokasi \\
7. & longitude & Varchar (20) & Longitude Lokasi \\
\hline
\end{tabular}

Secara umum penjelasan untuk Tabel 5 ini menyerupai penjelasan pada Tabel 4 hanya saja pada tabel ini deskripsi data digunakan untuk mengidentifikasi lokasi kuliner yang ada di kabupaten Kudus.

4) Tabel User, pada tabel 6 ini digunakan untuk menyimpan data admin. Struktur data tabel user dapat dilihat sebagai berikut:

Tabel 6. Tabel User

\begin{tabular}{rlll}
\hline No & \multicolumn{1}{c}{ Field } & \multicolumn{1}{c}{ Type } & \multicolumn{1}{c}{ Keterangan } \\
\hline 1. & id_user* & Int (10) & Kode User $(1,2,3,4, \ldots)$ \\
2. & Nama & Varchar (30) & Nama \\
3. & email & Varchar (50) & Email \\
4. & password & Varchar (20) & Password \\
\hline
\end{tabular}




\subsection{Implementasi Antarmuka}

Pada bagian ini akan dibahas rancangan antarmuka (interface) dari sistem yang dibangun. Tahapan ini dilakukan untuk membuat tampilan atau desain dari sistem yang akan dibuat. Tahapan ini harus memenuhi kriteria yang mudah digunakan, menarik, dan nyaman pada saat digunakan user/ wisatawan karena itu tahapan ini merupakan tahapan yang paling penting. Atas hal tersebut dibuatlah rancangan antarmuka (interface) untuk memudahkannya.

1) Tampilan splash screen dan menu utama

Tampilan splash screen yaitu menampilkan tampilan pertama ketika user/ wisatawan mengoperasikan aplikasi. Menampilkan icon yang menunjukkan aplikasi persebaran objek wisata dan kuliner di Kabupaten Kudus. Selanjutnya akan muncul menu utama yang memuat Menu wisata, menu kuliner, menu tentang wisata. Menu wisata akan diarahkan pada kategori wisata yang akan dikunjungi oleh user, sama hal nya dengan menu wisata, menu kuliner juga diarahkan pada beberapa pilihan kategori yang nantinya dapat dipilih oleh user/ wisatawan, sedangkan pada menu tentang aplikasi akan diarahkan ke info tentang aplikasi yang ada pada aplikasi tersebut.
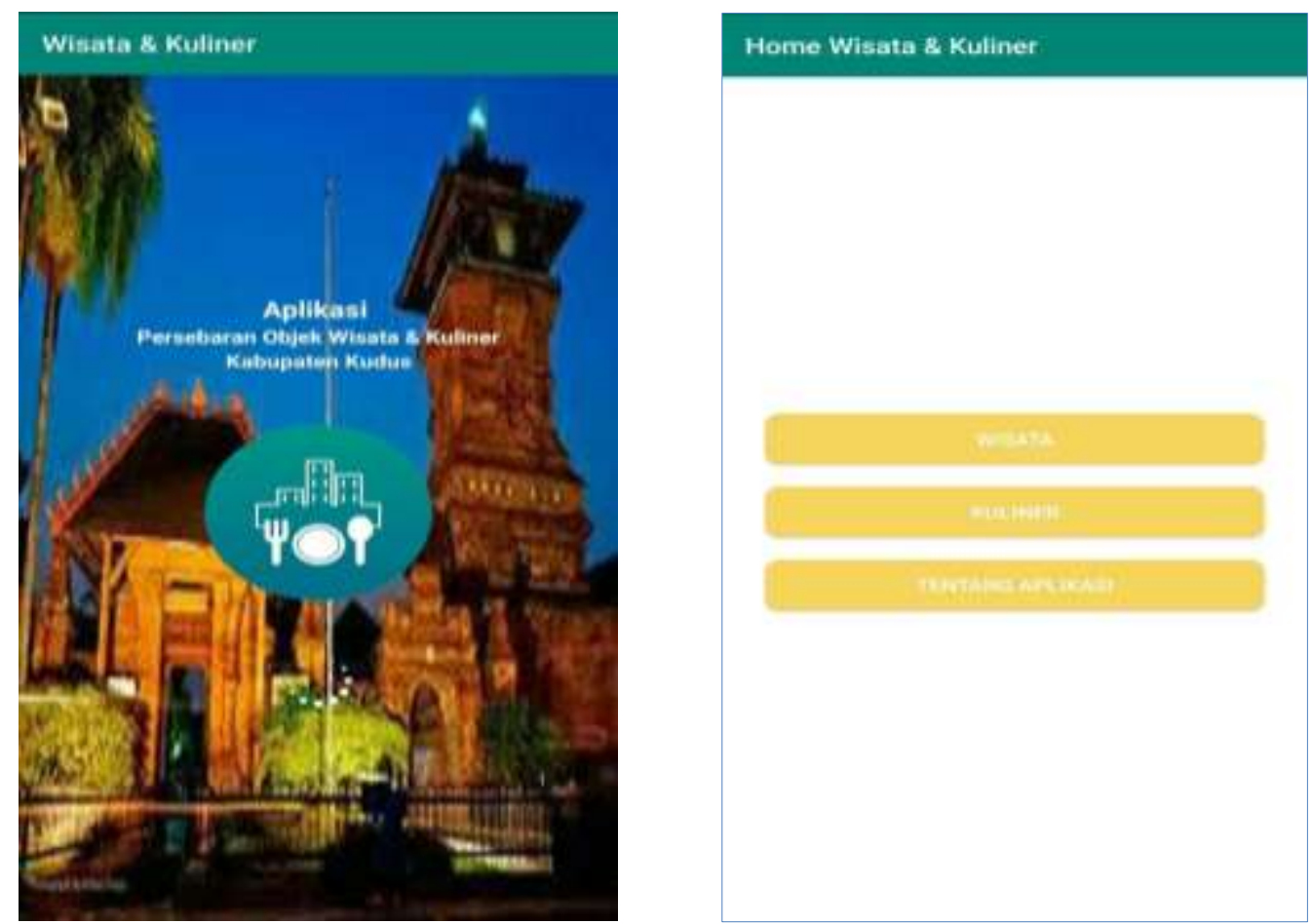

Gambar 4. Splash Screen dan Menu Utama

Tampilan splash screen sebagaimana tampak pada Gambar 4 akan muncul di layar dengan durasi kurang lebih 5 sampai dengan 10 detik sebelum beralih ke layar Menu Utama, bergantung pada prosesor yang digunakan oleh smartphone dan sisa memory yang tersedia pada internal RAM. Namun demikian tampilan akan beralih menjadi tampilan daftar Menu Utama secara langsung apabila user mengetuk layar di sembarang lokasi saat Splash Screen masih muncul.

2) Tampilan Menu Tentang Aplikasi

Halaman ini berisi tentang deskripsi dan informasi sejumlah fitur yang ada pada aplikasi. Menu tentang aplikasi, ini menjelaskan tentang seputar wisata apa saja yang dapat diakses pada aplikasi ini dan menjelaskan kuliner khas Kabupaten Kudus yang dapat ditemui dengan mudah. Penjelasan disampaikan secara singkat disertai dengan versi software dan identitas developer. 


\section{3) Tampilan Sub Menu Wisata dan Kuliner}

Halaman ini berisi tentang pilihan pada masing-masing kategori dengan berdasarkan dua pilihan utama yakni Wisata dan Kuliner. Untuk pilihan Wisata terdapat beberapa submenu yang meliputi sejumlah jenis-jenis tempat wisata seperti wisata religi, wisata agro, wisata budaya, dan wisata ekologi. Sedangkan dalam pilihan Kuliner terbagi dalam tiga kategori seperti rumah makan, restoran dan makanan khas.

4) Tampilan Daftar Menu Wisata dan Kuliner

Pada halaman ini berisi tentang daftar menu wisata dan kuliner yang merupakan tampilan ketika user menentukan salah satu kategori dari wisata dan kuliner.
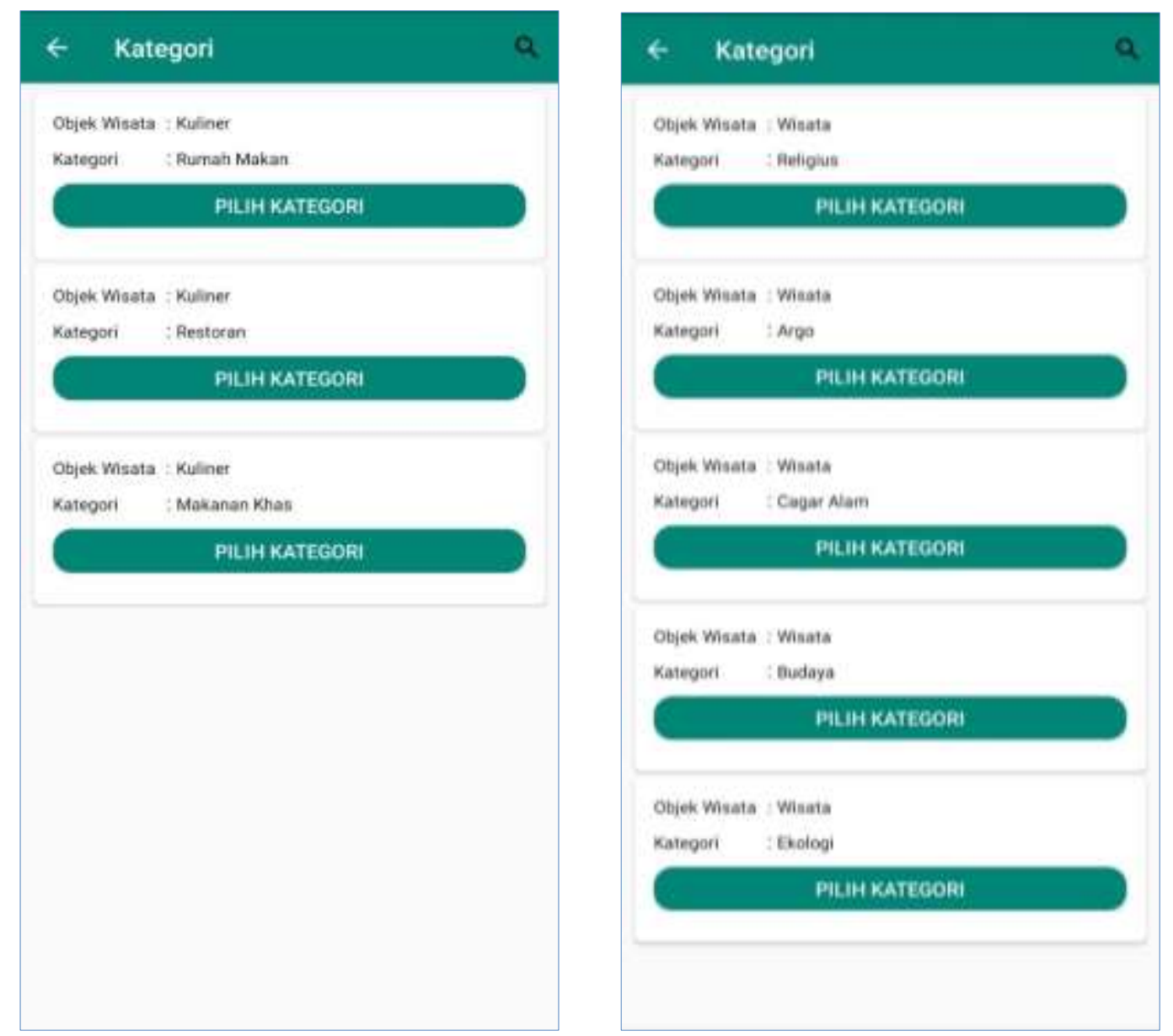

Gambar 5. Sub Menu Wisata dan Kuliner

Pada Gambar 5 detail untuk masing-masing kategori sub menu wisata dan kuliner ditampilkan untuk memudahkan user mempersempit domain pencarian data sehingga proses pemaparan lokasi atau informasi detil lainnya dapat ditampilkan lebih cepat.

\section{5) Tampilan Halaman Rute Wisata}

Halaman rute wisata ini muncul setelah user memilih menu tombol "Menuju Lokasi" yang tersedia pada menu wisata maupun menu kuliner. Engine pada Google Map akan menunjukkan rute dengan waktu tempuh terpendek untuk menuju lokasi, bukan berdasarkan pada jarak terpendek. Sinkronisasi sinyal GPS pada unit smartphone secara periodik akan merubah jarak dan waktu tempuh menuju lokasi serta mengupdate posisi smartphone mengikuti laju kecepatan pergerakan smartphone. Terkait dengan proses updating tersebut terdapat kemungkinan rute yang telah direkomendasikan akan berubah dikarenakan sejumlah hal misalnya terjadi kemacetan, terdapat penutupan jalan, atau posisi smartphone pengguna yang tidak 
mengikuti jalur rute yang sudah direkomendasikan sebelumnya [9]. Tampilan layar dari Rute Wisata/Kuliner dapat dilihat pada gambar berikut ini
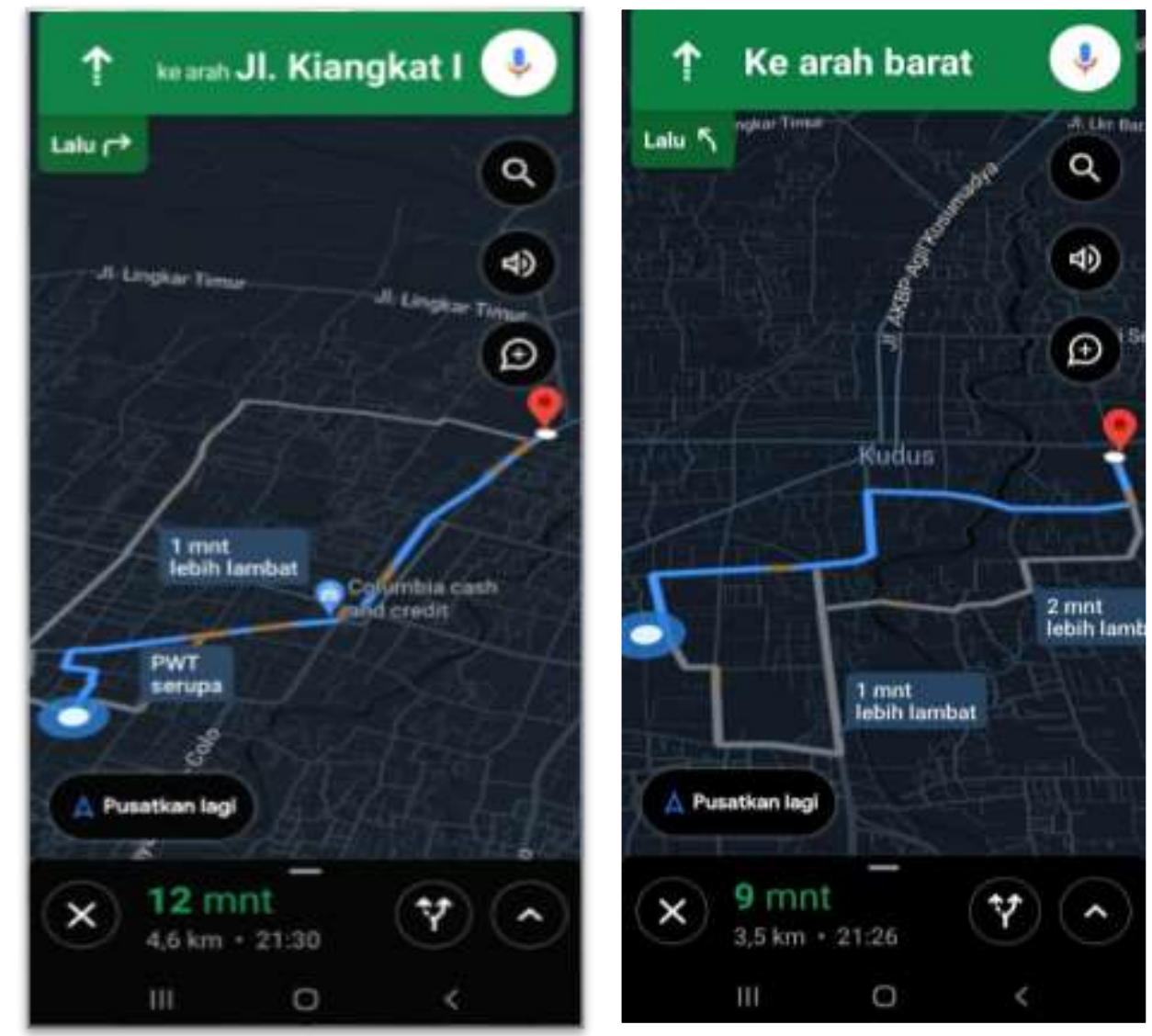

Gambar 6. Halaman Rute Menuju Lokasi Wisata / Kuliner

\section{KESIMPULAN}

Berdasarkan penelitian pengembangan aplikasi sistem informasi geografis persebaran obyek wisata dan kuliner di kabupaten Kudus ini dapat diambil beberapa kesimpulan bahwa dalam penelitian dapat menghasilkan aplikasi sistem informasi geografis dengan menggunakan smartphone Android yang dapat mempermudahkan user/wisatawan dalam mencari informasi mengenai lokasi menuju tempat wisata atau kuliner. Dengan berdasarkan kategori yang telah dipilih tersebut user/ wisatawan dapat melihat peta disertai rute perjalanan ke lokasi yang akan dituju. Serta dapat digunakan sebagai media promosi untuk mengenalkan pariwisata di Kabupaten Kudus, melalui kemudahan mendapatkan informasi yang lebih detil terkait dengan sejumlah potensi yang dimiliki Kabupaten Kudus. Integrasi sistem informasi dengan engine pada Google maps memberikan sejumlah keuntungan yang memungkinkan wisatawan dapat menuju lokasi wisata dengan lebih cepat dan terhindar dari kesalahan rute.

\section{SARAN}

Berdasarkan implementasi pada aplikasi, maka ada beberapa saran yang dapat dijadikan sebagai perbaikan atau penelitian lanjutan agar dapat dibangun aplikasi sistem informasi geografis yang lebih baik. Aplikasi yang dirancang dapat dikembangkan dari segi tampilan atau user interface untuk memudahkan pengaksesan dan pengontrolan perangkat saat pengguna 
sedang di perjalanan. Mode tampilan street-view perlu dijadikan sebagai pilihan bentuk tampilan untuk lebih memudahkan user mengidentifikasi lokasi bukan hanya dari perspektif bird-view sekaligus untuk meningkatkan akurasi dalam penentuan lokasi [10]. Perlu pengembangan modul updating informasi wisata dan kuliner yang dapat dilakukan secara langsung menggunakan perangkat smartphone sebagai alternatif pelengkap dari modul berbasis web yang sudah ada.

\section{DAFTAR PUSTAKA}

[1] T. Listyorini dan R. Meimaharani, "Aplikasi Wisata Kuliner Kota Kudus," Seminar Nasional Teknologi Informasi, 2017.

[2] R. P. Agrarian, A. Suprayogi dan B. D. Yuwono., "Pembuatan Aplikasi Mobile Gis Berbasis Android Untuk Informasi Pariwisata Di Kabupaten Gunung Kidul," Jurnal Geodesi Undip, April 2015.

[3] I. Muttaqin, I. Permana dan F. N. Salisah, "Aplikasi Navigasi Objek Wisata Kabupaten Lingga Berbasis Mobile,” Jurnal Ilmiah Rekayasa dan Manajemen Sistem Informasi, vol. 3, no. No.1, pp. 1-10, Februari 2017.

[4] M. Afrina, A. Ibrahim dan T. S. Simarmata, "Pengembangan Sistem Informasi Pariwisata Kota Palembang," Jurnal Sistem Informasi (JSI), vol. 8, no. No.2, Oktober 2016.

[5] E. Kurniadi dan H. Budianto, "Rancang Bangun Aplikasi Wisata Kabupaten Kuningan Berbasis Android Menggunakan Metode Location Based Service (LBS)," Jurnal Cloud Information, vol. 3, no. No.2, Maret 2018.

[6] G. H. Basith dan D. Kurniadi, "Perancangan Sistem Informasi Pemetaan Pariwisata Garut Berbasis Geografic Information System dan Andorid," Jurnal Algoritma Sekolah Tinggi Teknologi Garut, vol. 14, no. No.1, 2017.

[7] Pressman, R, "Software Engineering: A Practitioner's Approach", McGraw-Hill Eucation, 2014, ISBN:007769774X, Singapore.

[8] The Editor of Encyclopaedia Britannica, "Latitude and Longtitude : Geography", https://www.britannica.com/science/latitude, diakses tanggal 29 Oktober 2020.

[9] Devoe, Jiva, Jay Jacobson, and Nicholas Estes. "Intelligent dynamic route selection based on active probing of network operational characteristics." U.S. Patent Application No. 09/970,398.

[10] Zamir, Amir Roshan, and Mubarak Shah. "Accurate image localization based on google maps street view." European Conference on Computer Vision. Springer, Berlin, Heidelberg, 2010. 